\title{
Establishment of comprehensive experimental platform for engineering education
}

\author{
Chen Yang ${ }^{\mathrm{ab}}$, Li Sun ${ }^{\mathrm{ab}}$ \\ ${ }^{a}$ Key Laboratory of Low-grade Energy Utilization Technologies and Systems, Chongqing University, Ministry of Education, \\ No.174,Shazheng Street,Shapingba District, Chongqing,400044,China \\ ${ }^{b}$ College of Power Engineering, Chongqing University,No.174,Shazheng Street,Shapingba District, Chongqing,400044,China
}

\begin{abstract}
As a technological revolution in the field of modern energy, distributed energy system provides an opportunity for experimental teaching reform of energy engineering courses. Building energy engineering is introduced in the frame structure of the comprehensive experiment teaching platform, and according to the special function of the different modules, developed many experimental curriculum design, which will be the innovation and improvement of traditional experimental teaching mode. Comprehensive experimental teaching platform for the Green Island and many experiment courses of development are different from traditional classroom teaching and experiment teaching, which is a new teaching method and experimental platform aiming at studying more in-depth research in the power engineering students' exclusive domain. The different distributed energy subsystem modules of this experimental platform have good compatible general interfaces, whose subsystems can run independently or combine multiple interconnections. The platform improves students' comprehensive quality and creative ability, which is conducive to improve the comprehensive utilization efficiency of lab while making the students to have a systematic and comprehensive understanding of distributed energy system, providing new ideas for the teaching of energy students.
\end{abstract}

Keywords: Distributed energy system, Experimental platform, Teaching mode

\section{Introduction}

Energy and environment issues have been the main bottleneck which limit the sustainable development of China's economy. Adjusting energy structure, improving energy efficiency, perfecting safety of energy industry and solving environmental pollution have become the focus of the energy all over the country.

Distribution of distributed energy system is the main research issue on the demand side of cascade utilization of energy, as well as the comprehensive utilization of resources and renewable energy equipment, which is based on resources, environment and economic benefits the principle of optimization. According to the different demands of users on various energy resources, the system integrates the supply and demand optimization of resource allocation, and adopts the new energy system with demand response design and modular combination [1].

At present, the whole world is promoting construction of the second-generation energy system which is different from tradition energy system, such as carrying out legislative preparations and developing relative equipment. The second-generation energy system has six characteristics. They are diversified fuel, network, combined cooling heating and power, intelligent control and informational management, smallscaled equipment and environment protection. Combined cooling heating and power, small-scaled equipment and environment protection represent main directions of energy technology development: the

\footnotetext{
* Manuscript received January 26, 2018; revised July 5, 2019.

Corresponding author. Tel.: +8613628321803; E-mail address: yxtyc@ cqu.edu.cn.

doi: $10.12720 /$ sgce.8.5.620-626
} 
exploitation and utilization of renewable energy, the rise of distributed power supply technology and sustainable development of combined cooling heating and power.

In recent years, the hybrid systems combined with the solar energy, the wind energy and the power storage systems have been built and in operating [2,3]. The hybrid wind/solar distributed generating (DG) system has the advantages of clean and renewable, however, the cost, the electricity efficiency and the reliability of energy supply are still the important issues that need to be considered [4-6]. The unit sizing of the hybrid wind/solar DG system has a huge impact on the performance of the whole system. Therefore, it should be taken into consideration during the design phase of the whole hybrid system. And the integration of the wind and solar energy in the hybrid system becomes complex and requires consideration regarding grid stabilization [7] The hybrid wind/solar/fuel cell DG system is combined with wind energy system, the photovoltaic power generation system and the fuel cell system comprising the fuel cell stacks and an electrolyzer, which is used for a long period of time power storage [8].

Because of the country's acceleration of teaching reform and the energy markets' urgent demand of the distributed energy professionals, the teaching mode and teaching method for undergraduate and graduate students is of great importance to develop and improve.

Educators all over the world have made a lot of exploration and research on innovative teaching of power engineering students. Shuxian Lun thinks that most of the professional test system currently used in universities doesn't have the functions of light intensity and temperature to simulate the natural environment, which is different from the actual output power of the system. In addition, experiments to test the connection between the distributed energy and the grid will bring risks to the safety of the operator and the security of the grid [9]. Fei Jingzhou believes that professional comprehensive experiment projects of energy power, usually require large-scale laboratory equipment large volume, high cost, the experimental process often involves high temperature, high pressure and high speed and high risk, energy and power to carry out a wide range of professional comprehensive experiment of large-scale professional project. The students lack the necessary training to make a systematic and comprehensive understanding of the energy system and the large power plant. The lack of comprehensive experimental teaching conditions and the lack of experimental training have become an important factor affecting the quality of the training of energy power professionals [10]. Liu Chunhui believes that new energy science and engineering as a new major are open at home and abroad, so there is almost no mature experience in teaching methods and training plans. So it is necessary for students to apply their knowledge to specific subject courses, and the need for joint establishment and cooperation between universities and enterprises [11].

Therefore, Chongqing university integrate own teaching characteristic and peer teaching experience both at home and abroad, put forward the "experimental teaching system based on green island", which can be used in the theory and demonstration teaching to ensure the cascade utilization of distributed energy system, as well as scientific research [12-13].

\section{Construction Goal}

Experimental teaching system of green energy island provides a frontier, open and diversified experimental research platform for teachers and researchers in the professional and academic construction. With further efforts, it will become the first-class, comprehensive, integrated experimental base of energy and power, and it will attract domestic colleges and universities, research institutes, industrial enterprises to cooperation in our school with first-class demonstration of energy use practice base [14].

The goal of "Experimental Teaching System of Green Energy Island" is guiding the practice with theory, focusing on the innovation of thinking, encouraging scientific exploration, combining the concept of teaching, theoretical teaching, experimental teaching, engineering practice with Frontier Science and Technology closely, to cultivate Engineering, Applied, Management of high-quality personnel With international perspective and innovative ability $[15,16]$, It will be built into a new experiment teaching system and an innovation ability training centre for power and engineering with distinctive characteristics, especially in the southwest of China, forming a powerful demonstration effect and a broad radiative effect. 


\section{Construction Planning}

Combined with the fact of the undergraduate training plan, considering the aspects of experimental course construction, experimental content update and the construction of student science and technology innovation platform. The following plans are put forward.

(1) Based on green energy island, we will build distinctive courses of energy and power professional experiment. with emphasis on students' ability of practice and innovation awareness.

(2) The series of courses focus on the topics of new energy utilization, energy saving and emission reduction, covering the main research directions and main courses of energy and power engineering majors, and greatly extending its depth and breadth.

(3) We will establish a new experimental system and experimental teaching content, strengthen the construction of the characteristic experimental project, which the transformation of teachers' scientific research to undergraduate teaching experiment, and the proportion of comprehensive innovative experiments reach above $60 \%$.

\section{Construction Program}

The experiment teaching system of green island bases on the overall concept and starts to change the original experiment teaching from the fundamental construction of the new experimental teaching system, thereby breaking the limitations of the traditional curriculum in the experimental teaching system to build a disciplined platform as the centre and to advance energy utilization system as the main line of the independent experiments teaching system. On the basis of the discipline, the contents of all the experimental courses are integrated and optimized, and a new set of specialized experimental elective courses is added to make them not only pay attention to the systematization of the longitudinal knowledge of the majors, but also pay attention to the horizontal between disciplines, majors and disciplines' interaction and penetration of knowledge, so that experimental teaching can maximize the potential of students to explore knowledge and creativity of students to develop creativity and innovative ability to improve the overall quality[12,16].

The project plans to build a series of experimental courses with the green energy system, as shown in Fig. 1.

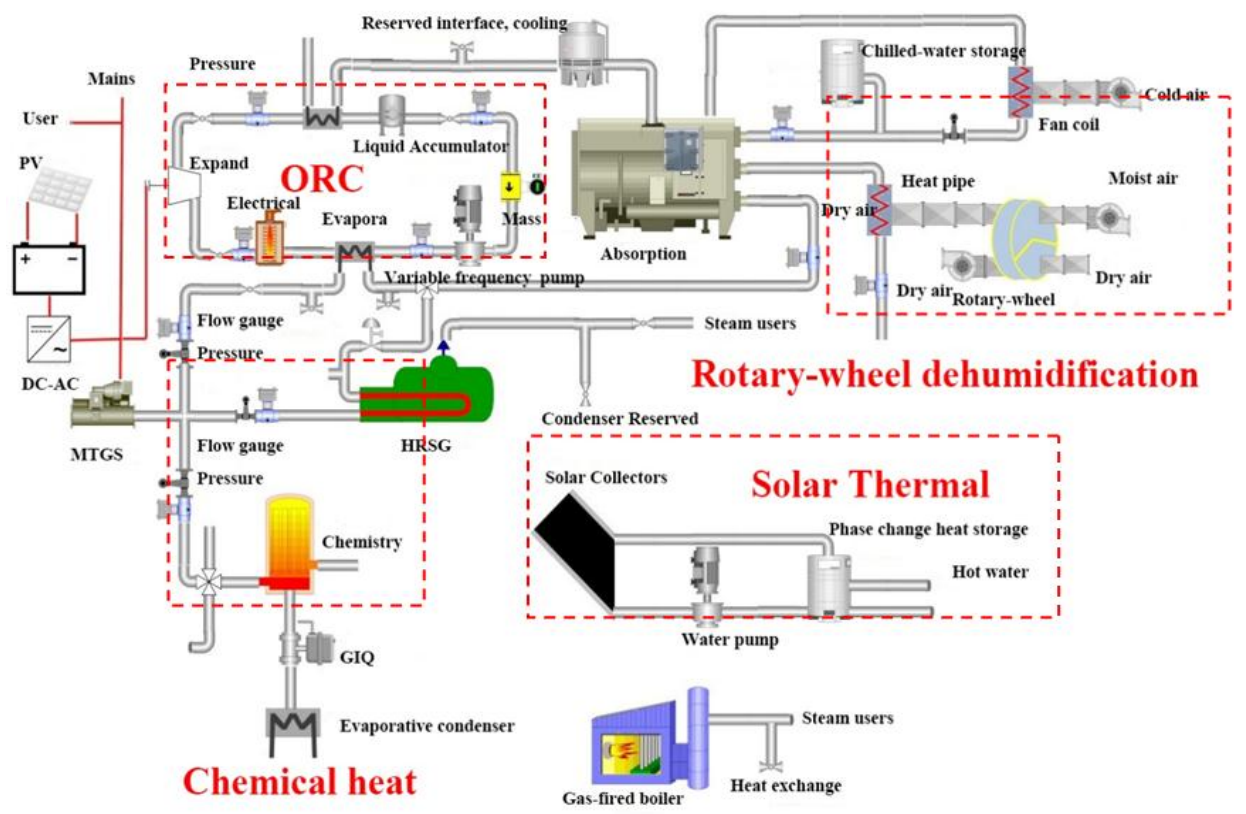

Fig. 1. The overall construction plan of "Experimental teaching system of green energy island". 
When the system starts running, the micro gas turbine is turned on firstly, and then the ORC, absorption refrigeration unit, rotary dehumidifier, waste heat boiler and other equipment are gradually started.

Features of the system:

(1) The exhaust of the micro gas turbine is divided into three parts. One part enters the ORC system to generate electricity, one part enters the waste heat boiler to produce steam, and some of it enters the chemical regenerative system for heat storage.

(2) The micro gas turbine and solar photovoltaic power generation are matched with the electric load. Considering the high exhaust temperature of the micro gas turbine, the whole generation efficiency can be improved by using ORC (organic Rankine cycle).

(3) The exhaust through the ORC system continues to drive absorption refrigerating unit, as well as the rotary dehumidifier, which realized independent control of the temperature, humidity, and improved absorption refrigerating supply/return water temperature and the COP of the absorption refrigerating unit. Eventually exhaust temperature will reduce to $90{ }^{\circ} \mathrm{C}$.

(4) The absorption refrigeration system can make use of chilled water to realize sensible heat ice storage with chilled-water storage tank.

(5) Collecting heat by using the solar collector and storing heat in the way of phase change heat storage by using the heat storage system, realized storage of discrete solar energy. So, the hot water load can be provided by solar energy.

(6) The whole system, combined with different conditions, adopts different heat storage methods: sensible heat storage, latent heat storage and chemical energy storage.

The main energy system is based on the CCHP system and supplemented by renewable energy while taking the intelligent scheduling as the core. There are lots of demands for energy, such as electricity, heat and cold. At the same time, with the use of micro gas turbine, supplemented by solar energy, wind energy, Plants carbon-absorption, and other means of energy-saving and emission reduction, we'd like to create low-carbon, energy saving, intelligent energy experiment system [6].

"Experiment teaching system of green island" framework shown in Fig. 2. It is divided into three series with four experimental modules:

(a) Energy conversion experiment system.

In the energy conversion process, the most important conversion process is to convert the chemical energy of fuel into heat energy through combustion. Converting the chemical energy of fuel into heat energy is achieved in the combustion equipment (main combustion equipment has boilers and various industrial furnaces). The conversion of thermal energy into mechanical energy is usually done in the heat engine. At the same time, the engine can provide power for all kinds of machinery. So, it is also called power machine.

(b) Energy storage experimental system.

The storage of energy is very much more important. The energy and demand energy obtained by most of the energy conversion or utilization systems are often inconsistent. To make the process of using energy continuous, there must be some form of energy storage or special storage equipment. The focus of research on the active class is the storage of mechanical energy and heat energy.

(c) The experimental system of energy utilization.

The effective utilization of energy is the most important problem in energy utilization. Usually, the effective utilization of energy is to consume the same energy and get more benefits, or to get the same benefits which will consume less energy.

Three series of experiments, four experimental modules which are distinct and increasing step by step build a comprehensive practical experimental teaching system of knowledge learning, engineering training, ability training and innovation.

The following new professional experiment courses can be set up for the students who major in energy and power engineering when the project "Experimental Teaching System of Green Energy Island" is completed. 
(1) According to the professional experiments in "Experimental Teaching System of Green Energy Island", three separate courses will be set up. These are elective experiment courses which are integrated, designed and large. These courses are in 5th, 6th, 7th semester. Each semester provides students with 48 class hours of elective experiment teaching courses. Three semesters provide 144 class hours. The professional teaching experiment has been included in undergraduate education programs for students enrolled in 2017.

(2) Curriculum design: $9 \times 2$ weeks for students who major in energy and power engineering

(3) Professional innovation experiment teaching session: 36 class hours for students who major in energy and power engineering

(4) SRTP, science and technology competition, independent engineering practice (optional) $1 \times 2$ weeks

(5) Graduation thesis: 18 weeks for students who major in energy and power engineering

(6) Experiment study and graduate thesis for academic/professional postgraduate student or Master of Engineering

(7) Curriculum design, Graduation thesis and experiment study for undergraduate or postgraduate whose majors are similar to energy and power engineering

\begin{tabular}{|c|c|c|}
\hline \multirow{4}{*}{$\begin{array}{l}\text { Experim } \\
\text { ental } \\
\text { Teachin } \\
\text { g System } \\
\text { of green } \\
\text { energy } \\
\text { based on } \\
\text { Cooling } \\
\text { Heating } \\
\text { and } \\
\text { Power }\end{array}$} & $\begin{array}{c}\text { Energy } \\
\text { conversion }\end{array}$ & $\begin{array}{l}\text { Fuel: } \\
\text { Analysis of gas, liquid, solid and biomass fuel; } \\
\text { Combustion: } \\
\text { Combustion technology of gas, liquid, solid and biomass } \\
\text { fuel; } \\
\text { Combustion equipment: } \\
\text { Combustion equipment of gas, liquid, solid and biomass } \\
\text { fuel; } \\
\text { Energy conversion equipment: } \\
\text { Steam turbines, gas turbines, refrigerators, pumps, wind } \\
\text { turbines. }\end{array}$ \\
\hline & $\begin{array}{l}\text { Energy } \\
\text { storage }\end{array}$ & $\begin{array}{l}\text { Storage of mechanical energy: } \\
\text { The input, storage and output process of power in wind } \\
\text { energy conversion system; } \\
\text { Compressed air energy storage technology. } \\
\text { Thermal energy Storage: } \\
\text { Sensible heat storage: Thermal Storage used Thermal } \\
\text { Storage Material; } \\
\text { Latent heat storage: Thermal Storage used Phase Change } \\
\text { Thermal Storage Material. } \\
\text { Chemical energy storage: Thermal storage technology in } \\
\text { the endothermic and exothermic process of a matter in a } \\
\text { reversible reaction; } \\
\text { Underground aquifer thermal storage. }\end{array}$ \\
\hline & $\begin{array}{c}\text { Energy } \\
\text { utilization }\end{array}$ & $\begin{array}{l}\text { Energy Cascade Utilization: } \\
\text { Waste heat recovery technology; } \\
\text { Sintering waste heat recovery technology; } \\
\text { Heat transfer enhancement technology; } \\
\text { Heat pump technology; } \\
\text { Heat pipe technology. } \\
\text { Distributed energy: } \\
\text { Solar energy, wind energy, fuel cell and CCHP system; } \\
\text { Experiment on startup performance of micro gas turbine; } \\
\text { Gas fuel and renewable energy, CCHP and energy } \\
\text { storage technology. }\end{array}$ \\
\hline & $\begin{array}{l}\text { Monitoring } \\
\text { and control } \\
\text { of system }\end{array}$ & $\begin{array}{l}\text { Integrated control and simulation of CCHP system: } \\
\text { System energy efficiency analysis; } \\
\text { System Optimization; } \\
\text { Analysis of System control. } \\
\text { Control and simulation of Power generation } \\
\text { characteristic in distributed energy system: } \\
\text { Simulation of photovoltaic power system. } \\
\text { Hardware-in-the-loop Simulation of micro gas } \\
\text { turbine/fuel cell Hybrid Systems. }\end{array}$ \\
\hline
\end{tabular}

Fig. 2. Architecture diagram of experimental teaching system. 


\section{Conclusion}

The teaching mode of green energy island comprehensive experiment platform is an innovation of teaching mode and the reform of traditional experimental teaching mode, which is beneficial to the cultivation of students' comprehensive quality.

By the comprehensive innovation experiment teaching reform, students got the whole process engineering management major knowledge and management skills training, to enhance students understanding of distributed energy systems management integrity and systemic, laying the groundwork to be going to work for the future. The teaching practice shows that this new teaching mode is an effective teaching method for energy engineering majors, which is worth popularizing and applying.

(1) Emphasis on hot spots

Energy and environment are hot issues which are generally involved in China's economic development and people's life. The distributed energy system in this project is closely related to daily life, which is intended for undergraduates of relevant majors such as energy power, chemical industry, civil engineering, machine electricity. Students can deepen their understanding and broaden their horizons through collaborative research in practice.

(2) Emphasis on independent design

In the innovation experiment set up in this project, the laboratory will provide only basic experimental platform and analytical test methods, while students complete the whole experimental process autonomously. The whole process includes experimental purpose, scheme design, analytical measurement, result analysis and experimental report. Therefore, during the implementation of this project, we should try our best to provide long-term experimental condition support and theoretical guidance for students who are qualified and creative.

(3) Emphasis on system learning with independent course setting

The series of innovative experimental systems in this project are not only the relevant experimental courses, but also a short - term innovation project. Each experimental platform will have a realistic set of questions, which emphasize learning into complex, meaningful situations. By leading students to solve the problems in the real world, they will explore the concepts and principles behind the problems, thus improving their self-learning ability and guiding them to build a systematic knowledge structure.

(4) Encourage peak experience

It is very important to participate in science and technology competitions, academic conferences, publish articles and write patents for students in the process of cultivating innovative talents especially in the national and international competitions, in which allows student to get their feet wet. Such peak experiences are of irreplaceable value to cultivate students' vision, mind, sense of responsibility and mission sense. Therefore, during the implementation of this project, we should try our best to provide long-term experimental condition support and theoretical guidance for students who are qualified and creative.

\section{References}

[1] Kandpal TC, Broman, L. Renewable energy education: A global status review. Renewable and Sustainable Energy Reviews, 2014; 34: 300-324.

[2] Kellogg WD, Nehrir MH, Venkataramanan G, Gerez VG. Unit sizing and cost analysis for stand-alonewind, photovoltaic, and hybrid wind/PV systems. IEEE Trans Energy Convers, 1998; 13: 70-71.

[3] Vahid BF, Mohammad HM, Mohammad A. Optimal operation of autonomous microgrid including wind turbines. Renewable. Energy, 2016; 35:315-324.

[4] Lund H. Large-scale integration of wind power into different energy systems. Energy, 2005; 30:2402-2412.

[5] Notton G, Cristofari C, Poggi P, Muselli M. Wind hybrid electrical supply system: behavior simulation and sizing optimization. Wind Energy, 2001; 4:43-69.

[6] Chedid R, Rahman S. Unit sizing and control of hybrid wind-solar power systems. IEEE Trans Energy Conver, 1997;12:79-85.

[7] Lund H, Andersen AN, Ostergaard PA, Mathiesen BV, Connolly D. From electricity smart grids to smart energy systems-a market operation-based approach and understanding. Energy, 2012; 42: 96-102. 
[8] Lund H, Marszal A, Heiselberg P. Zero energy buildings and mismatch compensation factors. Energy Build, 2011; 43:16461654.

[9] Lun SX, Li CJ. Construction of virtual simulation practical teaching platform for new energy power distributed generation, Experimental technology and management, 2016; 33:111-114.

[10] Fei JZ, Cao YP, Exploration and practice of cultivating innovative talents in majors of energy and power, Experimental technology and management, 2016; 33:24-26.

[11] Liu CH, Li S, Exploration on practice teaching platform construction of new energy science and engineering specialty -Taking solar energy as a Case . Agriculture network information, 2015; 11: 147-148.

[12] Ciriminna, R, Meneguzzo, F, Pecoraino, M, Pagliaro, M. Reshaping the Education of Energy Managers. Energy Research \& Social Science, 2016, 21: 44-48.

[13] Khoshbakht M, Gou Z, Dupre K. Energy use characteristics and benchmarking for higher education buildings. Energy and Buildings, 2018, 164(4).

[14] Figueiró PS, Raufflet E. Sustainability in higher education: A systematic review with focus on management education. Journal of Cleaner Production 2015, 106: 22-33.

[15] Mälkki H, Alanne K, Hirsto L. A method to quantify the integration of renewable energy and sustainability in energy degree programmes: A finnish case study. Journal of Cleaner Production 2015, 106: 239-246.

[16] Sucic B, Lah P, Visocnik BP. An education and training program for energy managers in Slovenia - current status, lessons learned and future challenges. Journal of Cleaner Production 2017, 142: 3360-3369. 